\title{
Career Preference of Business Graduate in Bangladesh: A Case Study of Some Selected Private Universities
}

\author{
Mohammad Emdad Hossain ${ }^{1}$, Tabassum Siddique ${ }^{2}$ \\ ${ }^{1}$ Department of Business Administration, International Islamic University Chittagong, Bangladesh \\ ${ }^{2}$ Department of Business Administration, International Islamic University Chittagong, Bangladesh
}

\begin{abstract}
This paper attempts to investigate the career preference of business graduates of private universities in Bangladesh. A total number of 256 final year business students, irrespective of gender in 15 private universities located in Dhaka city have been interviewed. Majority of the respondents' preferred field for future career development are banks and multinational companies. More than average of the total respondents plans to seek employment in their chosen field specially after obtaining the bachelor's degree. The major business courses that have been chosen by the business undergraduate students for specialization are finance and banking, human resource management, accounting and marketing. Financial benefit and social status were the major motivations for the business graduates' career preference. In case of major reasons of motivation, the male respondents are highly influenced by the financial benefit, social status and good opportunities in the chosen field. On the other hand, the female respondents identified financial benefit, social status and job security as their most influencing reasons behind career preference.
\end{abstract}

Keywords: Career, Business Graduation, Private University JEL Classification Code: M12; M51

\section{INTRODUCTION}

$S^{1}$ TUDENTS approach higher education with varying aspirations, bringing a wide range of prior skills, knowledge, abilities and ambitions from secondary and further education. They arrive at the threshold of higher education by different routes and embark on very different career trajectories within higher education. A well-educated, well-trained population could propel a nation towards rapid economic growth. Business education is tremendously expanded in Bangladesh. Most of the public universities and private universities provide business education based on models and materials developed in the west, particularly from the UK and USA. In a study conducted upon the public and private university students of Bangladesh, (Shamsuddoha \& Khanam, 2003) found that business education is in the greatest demand by human resource developers and entrepreneurs, in comparison to science, social science, professional, vocational and other purpose oriented training. The private higher educational institutions in Bangladesh are presently growing at a rapid pace. This growth is happening not only in terms of number but also in terms of their contribution to produce skilled and qualified manpower. These growing numbers of private universities are getting more competitive by performing beyond their traditional teaching and researching. They are now challenged to contribute to society's economic and social development, which is the third mission of universities (Gibb, 1996) .

There can be few careers where knowledge of business would not be useful. There are some jobs where a business administration degree may be particularly useful. While many of these careers are open to graduates in any subject, some employers may specify, or give preference to, graduates in business-related subjects. The students are looking for a degree which furnishes them with a wide knowledge base, so improving their employment opportunities. Elaine and Kenneth (1995) found in a study that today's employers' prefer business graduates, although they also consider there to be a requirement for task-specific training. Many authors suggest five stages of Career development (Torrington, Hall, \& Taylor, 2005). These often involve occupational choice and preparation of work; organizational entry; early career; mid career and late career. This paper focuses on occupational choice and preparation of work that usually starts at the stage of higher education. The specific purpose of the study is to find out the career preference of the business graduates of private universities and the underlying reasons of such career choice.

For the economic development as a whole, it is important that the human resources are efficiently allocated. With this view in mind, there is a need to ascertain students' career preferences and their underlying reasons. The rationale of the present study is to facilitate the educators and policy makers for career counseling with a view to match the students' available qualities with the employer's desired qualities or industry requirements.

\section{Private Universities in Bangladesh}

Universities, both public and private, play a vital role in creating a pool of highly educated and trained specialists. Opportunities for good education are extremely limited in the country; the situation is particularly critical in the 
university level. A large number of prospective students cannot get admission due to limited seats available in small number of public universities. In 1992, the government, by an Act of Parliament, allowed establishment of private universities in Bangladesh. Since then, a large number of private universities have been opened in the country -mostly located in Dhaka and Chittagong. These universities are, no doubt, meeting the unfulfilled demand of higher education.

Different academicians, industrialists, retired bureaucrats, diplomats and philanthropists, took the initiative to establish universities under private management and ownership. The Government assented to this proposal as part of its policy of encouraging the private field. In 1992, the Government passed the Private University Act (PUA).

\section{Literature Review}

The occupational position or the sequence of occupational experiences that a person gains over his life time can be termed as career (Dessler, 2009), (Adamson, Doherty, \& Viney, 1998). Some authors defined career as a continuous movement among different challenges and responsibility levels (Bahtijarevic, 1999) and some defined it as a life journey (Baruch 2006). Developing a preference for it and planning the education accordingly, is the beginning of that journey. The concept of career is much broad and complex. But we are taking a narrower view of the term, reflecting the intention of individuals to become active in different career fields. Furthermore, career preference represents the self-selection of fields by individuals on the basis of their personal strengths and weaknesses, offering them the highest probability for success. (Shamsuddoha \& Khanam, 2003) in their study have found among 300 sample of public and private university students of Dhaka and Chittagong, the greatest opportunities of finding job are high for private university students, who are studying business. It has also found that these opportunities are high in private and banking field than that of multinational companies, government service and others. In Bangladeshi job markets especially the financial field, manufacturing field and telecommunication fields are the prime job-hubs and these field require business graduation (Khaled Shams Chisty, Munir Uddin, \& Kumar Ghosh, 2007). (Moy \& Lee, 2002) studied university undergraduates of Hong Kong, relating to their career intentions for Small and Medium enterprise (SME)s as against Multinational Companies (MNC)s. They found that job attributes are the most important factors that influence the choice of career among undergraduates. In their study the important job attributes influencing the undergraduates' in choosing their career have been categorized into three groups-the job itself, compensation or security and the company or work environment (Moy \& Lee, 2002). The university undergraduates of Hong Kong, rated long term career prospects as the most important job attribute affecting their career choice, followed by pay, job security and managerial relationship. (Moy \& Lee, 2002), (Huang \&
Sverke, 2007) have considered academic major, gender and personality to determine the relationship between these three variables and business undergraduates' preferred career with SMEs and MNCs. They found that the undergraduates who preferred to work in SMEs are mostly doing major in management and the students who preferred to work for MNCs are doing major in accounting, finance and marketing. Female preferred employment with MNCs but male preferred SMEs. Previous research on the relationship between higher education and employment undertaken by (Purcell, Elias, Davies, \& Wilton, 2005), (Elias, McKnight, Simm, Purcell, \& Pitcher, 1999), demonstrated the importance of subject studied.

Several studies have found that career choices are determined by different motives. The most cited motives influencing the career decision are: financial success and high income (Carter, 2003), need of autonomy and independence (Van Auken, Stephens, Fry, \& Silva, 2006), social recognition and status (Birley \& Westhead, 1994). Economic motives were considered less important than other objectives in a study (Baumol, 1993). (Josten, 2008) studied the motives behind self-employment in German context. Here these scholars surveyed more than 15,000 students at 37 German higher education institutions, and found that the most important drivers are working under one's own initiative (90.0\%), making better use of one's own capabilities $(81.2 \%)$, self deciding on working hours and place $(79.8 \%)$, being one's own boss $(76.4 \%)$ and realizing one's own business or product ideas $(74.0 \%)$. Interestingly, the chance of higher income $(55.9 \%)$ was ranked less essential in the study. In a holistic approach considering several career alternatives, upon 1,600 German undergraduate students by (Lautenschläger \& Haase, 2010), the findings revealed that high income and social recognition was not important for the individuals in their sample.

In the context of environment (of cultural, social, political and economic nature) as determinants of career choice, only a few aspects have been scrutinized to date. The most relevant influence seems to be the perceived social pressure from family, friends or significant other 'people of reference' (Ajzen, 1991). Of the five career development stages identified by (Greenhaus \& Callanan, 1994), occupational choice is perhaps one of those most influenced by family concerns, both present and anticipated. In addition to familial influence on an individual's preferences for combining work and family, research shows that the occupational choices made by parents can exert a direct influence on the career choices of their children. According to (Brown, 2002), family or group influence impact both the decision-making process and the career an individual chooses. Moreover, the economic situation, especially the conditions in the labor market and the stability of employment appear to impact career choices.

Even several studies have been conducted over the past few decades to explore the gender differences with respect to career decision. Researchers have investigated the factors affecting job preference decisions among male and female college students. The fields in which women intended to work were services, personal care, education 
and office work (Huang \& Sverke, 2007). Previous studies have shown that women tend to work in the public field and in occupations associated with lower wages. Whereas (Chevalier, 2007) discovered that men tend to be more career-driven and financially motivated.

A large number of studies have been conducted addressing career choice or intention from the perspective of eastern and western part of the world, business or nonbusiness students, student's or employers' perceptions. There is a void in the literature relating to business student's career preference in the context of Bangladesh, incorporating all types of job fields namely; entrepreneurship, all private and public job areas. Moreover the decision of business graduates' choice for a business major (specialization in a particular business subject) during their graduation, which is indicating their future career path, are also almost absent.

\section{Research ObJectives}

The aim of the present study is to find the career preference of the business graduates in the private universities of Bangladesh and to identify the major factors influencing the career preference. For this purpose, the focus has been on;

i. To investigate the BBA graduates selecting their career for livelihood;

ii. To know the time period of starting the career;

iii. To find out the motivating factors that prompt them to accept a job in an organization and

iv. To study the gender differences with respect to career preference and major influencing factors of the business graduates.

\section{Research Methodology}

\subsection{Data Selection}

The present study is qualitative in nature. The population for the study consisted of BBA final year students who are in private universities located in Dhaka city. There are 51 private universities in Bangladesh (UGC, 2010). Among these about 42 are running in Dhaka city, and most of these universities have BBA program, where there are nearly 81,811 business students have been studying. A Sample of 256 BBA final year students have been selected for data collection from 15 private universities in Dhaka. Among the sample students 139 (54.3\%) are male and $117(45.7 \%)$ are female [See appendix 1].

\subsection{Data Collection}

A closed ended questionnaire has been distributed among the students of BBA program of different private universities. Data have been collected from BBA final year students, both male and female. BBA students of final year are usually considered to have some clear and specific directions and reasonable self concepts. The students of final year were intentionally interviewed with the assumption that by this time they have chosen their specialization keeping their career goal in mind. The sample students have been chosen following convenience of sampling method. The data have been collected through face to face interview by the surveyor. With the cooperation of the faculties and students, the interviewers distributed the questionnaires during the class session.

\subsection{Sampling Frame}

Bachelor of Business Administration (BBA) is a four year honors degree, where students get the opportunity to get specialized into a particular discipline of business.(such as; Accounting, Finance, Banking, Marketing, Human Resource management, Management Information system, International business, etc) from third year and afterwards, on an average. Thus the sample students are taken from final year. Students were asked to indicate their career preference and the important reasons behind their preference and to rank the reasons according to importance. In line with the previous studies and the present context of Bangladesh, the study considered 12 reasons, namely; financial benefit, social status, job security, non-financial benefit, Parent's influence on career decision, good match with the capabilities for doing the job, good career opportunities in the field, being referred by someone, challenging and interesting job, freedom and independence at work place, childhood aspirations, inspired by family or friends or relatives.

\subsection{Data Analysis}

This study investigates the factors that influence Bangladeshi Business students while selecting their career preference. The study also investigates any actual difference among the career preference and factors influencing for choosing the career of male and female business students. The collected data were processed in SPSS software. Most of the questions were of nominal and ordinal scale characteristics, which only permit the calculation of number, frequency and the use of cross tables. Hence we also adopted the simple regression with business major (Accounting, HRM, Finance, Marketing) and career preference (teaching, banking, entrepreneur, Multinational Companies-MNC, Non-Government Organization-NGO, Government Service-GOVT, Small and Medium Enterprise-SME, Research Organization-RO, Non-Banking Financial Institute-NBF, Others) to find out the significance of the study.

\section{Career Preference of Business Undergraduates in Private Universities}

For the purpose of identifying the career preference, the business undergraduate students were asked to specify the field where they want to build up their career. The students were also asked to specify their area of interest in which they want to pursue their business major. Majority of the selected 256 business students came from four different businesses major: Finance and Banking (30.1\%), Human Resource Management (23.0\%), Accounting (18.4\%), and Marketing (14.5\%). Most of the business students like to build up their career in Banking field $(38.7 \%)$, $23.8 \%$ preferred to work in multinational companies, and $11.7 \%$ preferred teaching as their future career.

Among the 256 respondents simple majority $(57 \%)$ of them are reluctant to pursue further specialization on 
their area of interest. They are more likely to enter into the job market just after completing their BBA program and $40.6 \%$ like to start their career after completing their MBA [See appendix 2].

TABLE 1: CAREER PREFERENCE FIELD AND MAJOR DISTRIBUTION OF BUSINESS STUDENTS

\begin{tabular}{|l|l|l|l|}
\hline Field & Total & Business major & Total \\
\hline Teaching & $11.7 \%$ & $\begin{array}{l}\text { Human Resource } \\
\text { Management (HRM) }\end{array}$ & $23.0 \%$ \\
\hline Banking & $38.7 \%$ & Accounting & $18.4 \%$ \\
\hline Entrepreneur & $8.2 \%$ & Marketing & $14.5 \%$ \\
\hline $\begin{array}{l}\text { Multinational } \\
\text { company }\end{array}$ & $23.8 \%$ & $\begin{array}{l}\text { Management Infor- } \\
\text { mation system (MIS) }\end{array}$ & $4.3 \%$ \\
\hline NGO & $3.9 \%$ & Finance and Banking & $30.1 \%$ \\
\hline $\begin{array}{l}\text { Govt. service } \\
\text { Small and me- } \\
\text { dium enter- } \\
\text { prise }\end{array}$ & $7.4 \%$ & $\begin{array}{l}\text { Supply chain man- } \\
\text { agement }\end{array}$ & $\begin{array}{l}\text { International busi- } \\
\text { ness }\end{array}$ \\
\hline $\begin{array}{l}\text { Research or-5\% } \\
\text { ganization }\end{array}$ & $.8 \%$ & $\begin{array}{l}\text { Accounting Informa- } \\
\text { tion system (AIS) }\end{array}$ & $0.6 \%$ \\
\hline $\begin{array}{l}\text { Non banking } \\
\text { financial insti- } \\
\text { tution }\end{array}$ & $2.7 \%$ & $\begin{array}{l}\text { Total Quality Man- } \\
\text { agement (TQM) }\end{array}$ & 0 \\
\hline Others & $.8 \%$ & Others & $1.0 \%$ \\
\hline Overall & $100 \%$ & Overall \\
\hline
\end{tabular}

Source: Field survey

\section{Reasons behind Business UNDERGRADUATES' SPECIFIC CAREER Preference}

On the basis of the literature survey, 12 reasons have been identified that may affect the decision of sample respondents' career preference. Each of the respondents was allowed to select several reasons that they considered as important for their decision to choose specific career.

TABLE 2: Distribution of REASONS BEHIND CHOOSING CAREER

\begin{tabular}{|l|l|l|l|l|}
\hline Reasons & $\begin{array}{l}\text { Frequen } \\
\text { quen- } \\
\text { cy }\end{array}$ & $\begin{array}{l}\text { Res- } \\
\text { ponses in } \\
\%\end{array}$ & $\begin{array}{l}\text { Rotal } \\
\text { no. of } \\
\text { respon } \\
\text { pon- } \\
\text { dents }\end{array}$ \\
\hline Financial benefit & 167 & 65.2 & 1 & \\
\hline Social status & 145 & 56.6 & 2 & \\
\cline { 1 - 4 } Job security & 98 & 38.3 & 4 & \\
\cline { 1 - 3 } $\begin{array}{l}\text { Non financial } \\
\text { benefit }\end{array}$ & 23 & 9.0 & 11 & \\
\cline { 1 - 3 } Parent's influ- & 55 & 21.5 & 6 & \\
\hline
\end{tabular}

\begin{tabular}{|l|l|l|l|l|}
\hline $\begin{array}{l}\text { ence on career } \\
\text { decision }\end{array}$ & & & & \\
\hline $\begin{array}{l}\text { Good match } \\
\text { with the capa- } \\
\text { bilities for doing } \\
\text { the job }\end{array}$ & 96 & 37.5 & 5 & \\
\hline $\begin{array}{l}\text { Good career } \\
\text { opportunities in } \\
\text { the field }\end{array}$ & 103 & 40.2 & 3 & \\
\hline $\begin{array}{l}\text { Being referred } \\
\text { by some one }\end{array}$ & 24 & 9.4 & 10 & \\
\hline $\begin{array}{l}\text { Challenging and } \\
\text { interesting job }\end{array}$ & 38 & 14.8 & 7 & \\
\hline $\begin{array}{l}\text { Freedom and } \\
\text { independence at } \\
\text { work place }\end{array}$ & 25 & 9.8 & 9 & \\
\hline $\begin{array}{l}\text { Childhood aspi- } \\
\text { rations } 14\end{array}$ & 5.5 & 12 & \\
\hline $\begin{array}{l}\text { Inspired by fam- } \\
\text { ily or friends or } \\
\text { relatives }\end{array}$ & 30 & 11.7 & 8 & \\
\hline
\end{tabular}

\section{Source: field survey}

From the analysis of the above table it is observed that out of the 12 reasons that had been identified as reasons that may influence the choice of a job/career, financial benefit $(65.2 \%)$, social status $(56.6 \%)$, prevailing opportunities in the job market $(40.2 \%)$, job security $(38.3 \%)$, and acquired qualities for doing the job (37.5\%) were identified as extremely important. Here the respondents are seemed to be highly influenced by financial benefits and social status, which is different from the findings of the studies done by (Lautenschläger \& Haase, 2010) and (Josten, 2008). (King, 2003) and (Mayrhofer, et al., 2005) in their study also found that the security of traditional career is more tempting for graduates than the boundary less career. In the present study, childhood aspirations (5.5\%), nonfinancial benefits $(9.0 \%)$, known person's reference to get the job $(9.4 \%)$ and freedom and independence in the workplace $(9.8 \%)$ were least important reasons influencing business graduates career preference. In order to find out the most important reasons for choosing a specific career, the sample respondents were asked to rank the above mentioned 12 reasons according to their importance on their career choice. Financial benefits were chosen as the most important reason. The second important reason is social status and then good career opportunities in the field and job security.

\section{Gender Differences in Career Preference of Business Undergraduates:}

In terms of career preference, male respondents selected firstly banking field $(21.9 \%)$, secondly responded for multinational companies $(13.3 \%)$ and $6.3 \%$ preferred to be an entrepreneur. Whereas the first two fields for career development for female business graduates are same, except that they have also preferred teaching as an important field for career development [See appendix 3]. Male and female respondents showing almost similar 
career preference as the labor market for business graduates in Bangladesh is gendered to a limited extent.

It is remarkable that only $8.2 \%$ of the business students of undergraduate program in different private universities are interested to develop their career as an entrepreneur, where majority $(77 \%)$ of them are male respondents [See appendix 3]. A large quantity of researches proved that men are more inclined towards entrepreneurial business than women with similar background (BeckerBlease \& Sohl, 2007). Thus gender influences the intentions of men and women to involve and pursue entrepreneurial activities as their career.

For attaining the respondents' chosen career, highest responses $18.4 \%$ came in favor of finance and banking, then $9.8 \%$ for human resource management and $9.4 \%$ for marketing. While the female respondents mostly (13.3\%) selected human resource management, $11.7 \%$ finance and banking and $10.5 \%$ like to have their specialization in accounting [See appendix 4]. No significant difference was actually found in the respondents' decision of starting their career after their BBA and MBA degree. But it is to be noted that $1.6 \%$ of the male business students intended to pursue further specialization in their specific area of interest where a very negligible percentage $0.8 \%$ of the female respondents wants to pursue higher degree before attaining their chosen career [See appendix 2]. The following table shows the different reasons influencing the career preference of male and female business graduates.

In terms of career preference, male respondents selected firstly banking field $(21.9 \%)$, secondly responded for multinational companies $(13.3 \%)$ and $6.3 \%$ preferred to be an entrepreneur. Whereas the first two fields for career development for female business graduates are same, except that they have also preferred teaching as an important field for career development [See appendix 3]. Male and female respondents showing almost similar career preference as the labor market for business graduates in Bangladesh is gendered to a limited extent.

It is remarkable that only $8.2 \%$ of the business students of undergraduate program in different private universities are interested to develop their career as an entrepreneur, where majority $(77 \%)$ of them are male respondents [See appendix 3]. A large quantity of researches proved that men are more inclined towards entrepreneurial business than women with similar background (BeckerBlease \& Sohl, 2007). Thus gender influences the intentions of men and women to involve and pursue entrepreneurial activities as their career.

For attaining the respondents' chosen career, highest responses $18.4 \%$ came in favor of finance and banking, then $9.8 \%$ for human resource management and $9.4 \%$ for marketing. While the female respondents mostly (13.3\%) selected human resource management, $11.7 \%$ finance and banking and $10.5 \%$ like to have their specialization in accounting [See appendix 4]. No significant difference was actually found in the respondents' decision of starting their career after their BBA and MBA degree. But it is to be noted that $1.6 \%$ of the male business students intended to pursue further specialization in their specific area of interest where a very negligible percentage $0.8 \%$ of the female respondents wants to pursue higher degree before attaining their chosen career [See appendix 2]. The following table shows the different reasons influencing the career preference of male and female business graduates.

Table 3: Percentage Distribution of Reasons behind Choosing CAREer by Gender

\begin{tabular}{|l|l|l|}
\hline Reasons & $\begin{array}{c}\text { Male } \\
(\mathbf{\%})\end{array}$ & $\begin{array}{c}\text { Female } \\
(\mathbf{\%})\end{array}$ \\
\hline Financial benefit & 66.91 & 63.25 \\
\hline Social status & 58.27 & 54.70 \\
\hline Job security & 32.37 & 45.30 \\
\hline Non financial benefit & 7.91 & 10.26 \\
\hline Parent's influence on career decision & 17.99 & 25.64 \\
\hline $\begin{array}{l}\text { Good match with the capabilities for } \\
\text { doing the job }\end{array}$ & 36.69 & 38.46 \\
\hline $\begin{array}{l}\text { Good career opportunities in the } \\
\text { field }\end{array}$ & 45.32 & 34.19 \\
\hline Being referred by some one & 7.91 & 11.11 \\
\hline Challenging and interesting job & 14.39 & 15.38 \\
\hline $\begin{array}{l}\text { Freedom and independence at work } \\
\text { place }\end{array}$ & 12.95 & 5.98 \\
\hline Childhood aspirations & 6.47 & 4.27 \\
\hline $\begin{array}{l}\text { Inspired by family or friends or rela- } \\
\text { tives }\end{array}$ & 13.67 & 9.40 \\
\hline Total no. of respondents (n) & $\mathbf{1 3 9}$ & $\mathbf{1 1 7}$ \\
\hline
\end{tabular}

Source: field survey

The issue arising from this finding is that male and female business students are motivated to make their career decision by almost similar reasons, where there is difference only in terms of their importance. The male respondents are mainly motivated by the financial benefit $(66.91 \%)$, social status $(58.27 \%)$, good employment opportunities in their chosen field $(45.32 \%)$, good match with the qualities for doing the job (36.69\%) and job security $(32.37 \%)$. On the other hand, the female respondents identified financial benefit $(63.25 \%)$, social status $(54.70 \%)$, job security $(45.30 \%)$, having the qualities for doing the job (38.46\%) and good career opportunities in the chosen field $(34.19 \%)$ as their most influencing reasons behind career preference. Beside these, $17.99 \%$ of the male respondents and $25.64 \%$ of the female respondents have found parents' influence on their career preference as an influencing reason in this regard. here female respondents are more influenced by their parents' decision for choosing a career path. Both male and female respondents have identified childhood aspirations $(6.47 \%$ and $\$ .27 \%$ respectively) as least important reason for influencing their decision to choose a career.

\section{Discussion ABOUt the Findings}

No significant difference is actually observed for different genders in terms of career preference, time period of starting career and major reasons for motivating business student's career preference. Near about 100 students out of $256(39.06 \%)$, preferred career field is Banking. It was 
also found that the respondents are reluctant to choose small and medium enterprise, research organization and non-banking financial institutions. The most influencing reasons behind these career preferences are that, today's graduates value financial incentives and social status and recognition more. Fascination with banking services and private service in multinational companies has never been higher than at present. With the advent of private and foreign banks, the interest of youth in joining banks has only increased further. There are total 47 banks in Bangladesh (Private, nationalized, foreign, and specialized), operating in total of 8522 branches all over the country (Bangladesh Bank Annual report, 2010-11). Many foreign companies are also entering in to the country from past few decades due to the extensive government support. The prime reasons for attracting these graduates in theses fields are their lucrative pay package, the job security and prospective career growth and above all the growing job opportunities. The positive part of the study is that most of the sample business students chosen their business major with a clear idea about their prospective career. But these students seem to give less importance towards the need of post- graduation, which they will require to hold executive position in any business organization in course of their career progress.

Moreover, the regression analysis has revealed that the career preference dependent on business major where the value of regression coefficient is computed 0.814 , which is also significant at $0 \%$. In the regression model it is seen that the value of R2 has been 0.805 and that of adjusted $\mathrm{R} 2$ has been 0.762 . If we conclude with the help of the value of adjusted $\mathrm{R} 2$, it can be said that the dependent variable career preference (teaching, banking, entrepreneur, Multinational Companies-MNC, Non-Government Organization-NGO, Government Service-GOVT, Small and Medium Enterprise-SME, Research OrganizationRO, Non-Banking Financial Institute-NBF, Others) of the business graduates is explained to the extent of $76.2 \%$ by the business majors (Accounting, HRM, Finance, and Marketing) as taken by the students [See appendix 5].

\section{RECOMMENDATIONS}

It is seen in the present study that the majority business undergraduate students have a reasonably clear idea about the occupational direction that they wished to take after completing their courses and the qualifications required to achieve it. The findings of the study can be useful for both educators in their quest to orientate students in career path planning, and for policy-makers and practitioners to understand the graduates' career decisions. However, the following recommendations have been put forwards by the respondents:

i. Students need adequate knowledge and guidance in enabling them to make their choice regarding education and career.

ii. The schools, college, community and other careers guidance staff who advise higher education applicants, have to play a role to inform about the rela- tionship between prior qualifications, higher education courses and career opportunities.

iii. The university can design more market oriented, job related and practical courses and can make frequent workshop and seminar in collaboration with the different specialized person of different corporate fields. This will help these students to fill their gaps before they are gone actually in this competitive job market.

iv. Effective planning is required for the academic and even non-academic programs for the business undergraduates targeting towards developing their academic, technical and communication skills.

v. Through a career service department final semester students can be advised about their choice of profession and job prospects. Beside this frequent job fairs can be arranged through the career assistance program.

vi. Private universities should maintain a collaborative relationship with reputed industries, multi-national companies and corporate business houses, primarily to run students' internship program. This will immensely benefits the students, in relating their theoretical knowledge to the practical field. Moreover, practical knowledge acquired through internship gives an edge to private university graduates in the job market.

vii. A meaningful collaboration between private universities and industries, trade bodies and all other trade and commerce related entities can play a pivotal role in formulating a need-based higher education system.

\section{ConCLUSION}

For the greater interest of creating quality manpower for the country and for the transferability of skills and the reflective learning across the full spectrum of academic programs of study, students can safely be encouraged to make choices on the basis of enthusiasm and interest rather than narrowly employment-focused considerations. There is also a need to identify the constraints and opportunities faced by business graduates that influence their capacity to maximize their potential, in terms of both learning opportunities and access to careers.

\section{BiBLIOGRAPHY}

[1] Adamson, S. J., Doherty, N., \& Viney, C. (1998). The meanings of career revisited: Implications for theory and practice. British Journal of Management, 9, 251-259.

[2] Ajzen, I. (1991). The theory of planned behavior. The Organizational Behavior and Human Decision Processes, 50(2), 179-211.

[3] Bahtijarevic, S. F. (1999). Management Ijudskih Potencijala. Zagreb Golden marketing Zagreb.

[4] Bank, B. (July 28, 2012). Bangladesh Bank Annual Report 2010-2011. Retrieved from http:/ / www.bangladesh-bank.org/openpdf.php

[5] Baruch, Y. (2006). Career development in organizations and beyond: Balancing traditional and contemporary viewpoints. Human Resource Management Review(16), 125-138.

[6] Baumol, W. J. (1993). Toward operational models of entrepreneurship. Lexington (MA): Lexington Books: In Ronen, J. (ed.).

[7] Becker-Blease, J. R., \& Sohl, J. E. (2007). Do women-owned businesses 
have equal access to angel capital? Journal of Business Venturing, 22, 503-521.

[8] Birley, S., \& Westhead, P. (1994). A taxonomy of business start-up reasons and their impact on firm growth and size. Journal of Business Venturing, Journal of Business Venturing, 9(1) , 7-31.

[9] Boden, R. J. (2000). On the survival prospects of men's and women's new business ventures. Journal of Business Venturing, 15, pp. 347-362.

[10] Brown, D. (2002). The role of work and cultural values in occupational choice, satisfaction, and success: A theoretical statement. Journal of Counseling and Development, 80, 48-56.

[11] Carter, N. M. (2003). The career reasons of nascent entrepreneurs. Journal of Business Venturing, 18(1), 13-39.

[12] Chevalier, A. (2007). Education, occupation and career expectations: Determinants of the gender pay gap for UK graduates. Oxford Bulletin of Economics and Statistics, 69, 819-842.

[13] Dessler, G. (2009). Fundamentals of Human Resource Management. Content, competencies, and applications. Upper Saddle River: Pearson.

[14] Douglas, E. J., \& Shepherd, D. A. (2002). Self-employment as a Career Choice: Attitudes, Entrepreneurial Intentions, and Utility Maximization. Entrepreneurship Theory and Practice, 26(3), 81-90.

[15] Elaine M, O., \& Kenneth R, D. (1995). The position of marketing education: a student versus employer perspective. Marketing Intelligence \& Planning, 13(2), $47-52$.

[16] Elias, P., McKnight, A., Simm, C., Purcell, K., \& Pitcher, J. (1999). DfEE-CSUAGCAS-IER Moving On: Graduate careers three years after graduation. Manchester: Careers Service Unit, Institute of employment research.

[17] Etzkowitz, H. e. (2000). The future of the university and the university of the future: evolution of ivory tower to entrepreneurial paradigm. Research Policy, 29(2), 313-330. .

[18] Gibb, A. A. (1996). Entrepreneurship and Small Business Management: Can We Afford to Neglect Them in theTwenty-First Century Business School? British Journal of Management, 7(4), 309-321.

[19] Greenhaus, J. H., \& Callanan, G. A. (1994). Career management. London: Dryden Press.

[20] Harvey, L., Moon, S., Geall, V., \& Bower, R. (1997). Graduates' Work: Organisational change and students' attributes Birmingham, Centre for Research on Quality and Association of Graduate Recruiters. Birmingham: Centre for Research on Quality and Association of Graduate Recruiters.

[21] Huang, Q., \& Sverke, M. (2007). Women's occupational patterns over 27 years: Relation to family of origin, life careers, and wellness. Journal of Vocational Behavior, 70, 369-397.

[22] Johannisson, B., Handström, H., \& Rosenberg, J. (1998). University training for entrepreneurship: an action frame of reference. European Journal of Engineering Education, 23(4), 477-496.

[23] Josten, M. e. (2008). Gründungspotenziale bei Studierenden. Zentrale Ergebnisse der Studierendenbefragung an 37 deutschen Hochschulen. Bonn/Berlin: Bundesministerium für Bildung und Forschung (Hrsg.).

[24] Khaled Shams Chisty, K., Munir Uddin, G., \& Kumar Ghosh, S. (2007). The Business Graduates Employability in Bangladesh: Dilemma and Expected Skills by Corporate World. BRAC University Journal, 4(1), pp-1-8.

[25] King, Z. (2003). New or traditional careers? A study of UK graduates' preferences. Human Resource Management Journal, 13, 2-26.

[26] Lautenschläger, A., \& Haase, H. (2010). Universities: a hotbed of human resources for new firms? Journal of Small Business and Entrepreneurship, 23 (special issue), 747-759. Journal of Small Business and Entrepreneurship, 23(special issue), 747-759.

[27] Mayrhofer, W., Steyrer, J., Meyrer, M., Strunk, G., Schiffinger, M., \& Iellatchitch, A. (2005). Graduates' career aspirations and individual characteristics. Human Resource Management Journal, 15, 38-56.

[28] Moy, J. W., \& Lee, S. M. (2002). The career choice of business graduates: SMEs or MNCs? . Career Development International, 7(7/6), 334-347.

[29] Purcell, K., \& Elias, P. (2004). Is mass higher education working? Evidence from the Labour Market Experiences of Recent Graduates ' National Institute Economic Journal, November No. 90, October 60-74. National Institute Economic Journal, 90, 60-74.

[30] Purcell, K., Elias, P., Davies, R., \& Wilton, N. (2005). The Class of '99. A study of the early labour market experiences of recent graduates. Nottingham: DfES Publications.

[31] Shamsuddoha, \& Khanam. (2003). Development of Human Resources in Bangladesh: An Analysis of Institutional Supports. Retrieved from http:/ / ssrn.com/abstract=1295429

[32] Torrington, D., Hall, L., \& Taylor, S. (2005). Human Resource Management. Harlow: Prentice Hall.

[33] Van Auken, H., Stephens, P., Fry, F., \& Silva, J. (2006). Role model influences on entrepreneurial intentions: A comparison between USA and Mexico. International Entrepreneurship and Management Journal, 2(3), 325-336.

[34] Weldon, E., \& Vanhonacker, W. (1999). Operating a foreign-invested enterprise in China: Challenges for managers and management researchers. Journal of World Business, 34(1), 94-107.

\section{APPENDICES}

APPENDIX 1

NUMBER OF RESPONDENTS AND PERCENTAGE DISTRIBUTION BY GENDER

\begin{tabular}{|l|l|l|l|}
\hline Gender & Male & Female & Total \\
\hline No of respondents & 139 & 117 & 256 \\
\hline$\%$ of Total & $54.3 \%$ & $45.7 \%$ & $100.0 \%$ \\
\hline
\end{tabular}

APPENDIX 2

RESPONSES (IN \%) OF STUDENTS WHEN THEY WANT TO START THEIR CAREER

\begin{tabular}{|l|l|l|}
\hline When want to start career & Responses & Total \\
\hline After finishing BBA & $29.7 \%$ & \\
Male & $27.3 \%$ & \\
Female & & $57.0 \%$ \\
Total & $23.0 \%$ & \\
After finishing MBA & $17.6 \%$ & \\
Male & & $40.6 \%$ \\
Female & & \\
Total & \\
After finishing PhD or further \\
specialization or professional \\
degree & $1.6 \%$ & \\
Male & $8 \%$ & \\
Female & & \\
Total & & $100 \%$ \\
\hline Total & \\
\hline
\end{tabular}


APPENDIX 3

FIELD DISTRIBUTION OF BUSINESS STUDENTS' WANTS TO BUILD UP THEIR CAREER

\begin{tabular}{|c|c|c|c|}
\hline \multirow[t]{2}{*}{ Fields } & \multicolumn{2}{|c|}{ Gender } & \multirow[b]{2}{*}{ Total } \\
\hline & Male & Female & \\
\hline Teaching & $4.3 \%$ & $7.4 \%$ & $11.7 \%$ \\
\hline Banking & $21.9 \%$ & $16.8 \%$ & $38.7 \%$ \\
\hline Entrepreneur & $6.3 \%$ & $2.0 \%$ & $8.2 \%$ \\
\hline Multinational company & $13.3 \%$ & $10.5 \%$ & $23.8 \%$ \\
\hline $\mathrm{NGO}$ & $2.0 \%$ & $2.0 \%$ & $3.9 \%$ \\
\hline Govt. service & $2.7 \%$ & $4.7 \%$ & $7.4 \%$ \\
\hline $\begin{array}{l}\text { Small and medium en- } \\
\text { terprise }\end{array}$ & $1.6 \%$ & $.4 \%$ & $2.0 \%$ \\
\hline Research organization & $.8 \%$ & $.0 \%$ & $.8 \%$ \\
\hline $\begin{array}{l}\text { Non banking financial } \\
\text { institution }\end{array}$ & $1.2 \%$ & $1.6 \%$ & $2.7 \%$ \\
\hline Others & $.4 \%$ & $.4 \%$ & $.8 \%$ \\
\hline Total & $54.3 \%$ & $45.7 \%$ & $100.0 \%$ \\
\hline
\end{tabular}

\section{APPENDIX 4}

BUSINESS MAJOR SELECTION FOR CAREER ATTAINMENT

\begin{tabular}{|c|c|c|c|}
\hline \multirow[t]{2}{*}{ Business major } & \multicolumn{2}{|c|}{ Gender } & \multirow[b]{2}{*}{ Total } \\
\hline & Male & Female & \\
\hline HRM & $9.8 \%$ & $13.3 \%$ & $23.0 \%$ \\
\hline Accounting & $7.8 \%$ & $10.5 \%$ & $18.4 \%$ \\
\hline Marketing & $9.4 \%$ & $5.1 \%$ & $14.5 \%$ \\
\hline MIS & $2.7 \%$ & $1.6 \%$ & $4.3 \%$ \\
\hline Finance and Banking & $18.4 \%$ & $11.7 \%$ & $30.1 \%$ \\
\hline $\begin{array}{l}\text { Supply chain man- } \\
\text { agement }\end{array}$ & $2.0 \%$ & $.8 \%$ & $2.7 \%$ \\
\hline International business & $3.9 \%$ & $1.6 \%$ & $5.5 \%$ \\
\hline Others & $.4 \%$ & $1.2 \%$ & $1.6 \%$ \\
\hline Overall & $54.3 \%$ & $45.7 \%$ & $100.0 \%$ \\
\hline
\end{tabular}

APPENDIX 5

SIMPLE REGRESSION

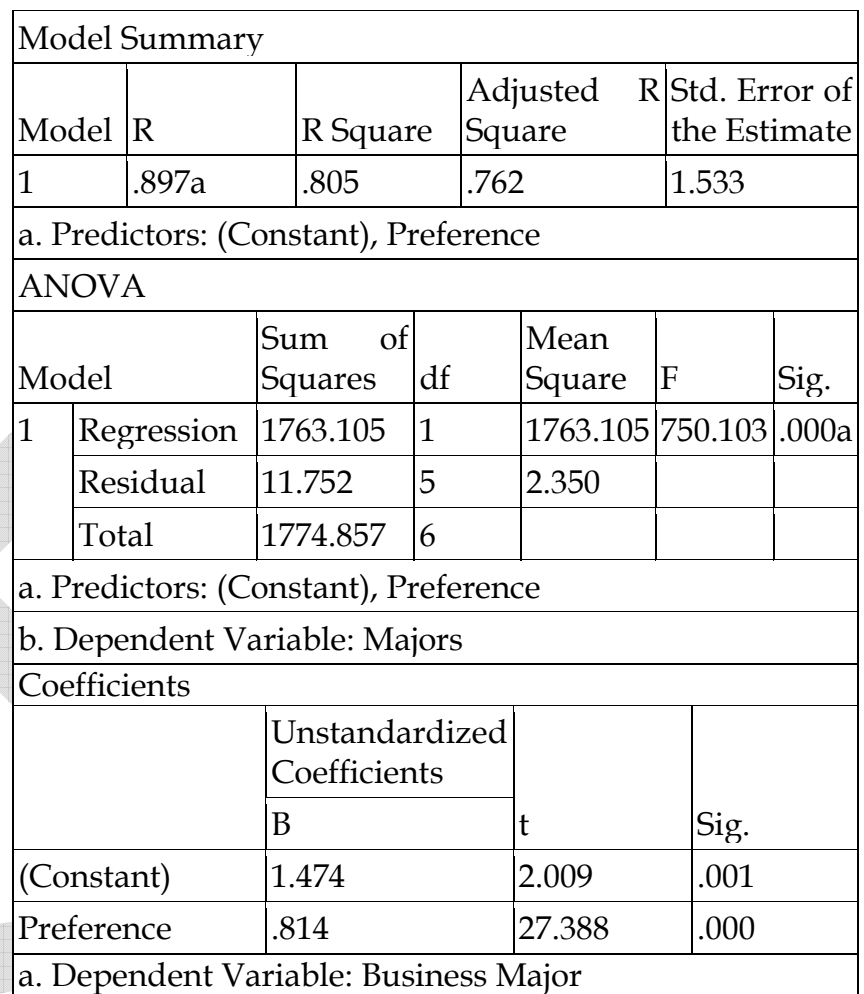

